\title{
TODUS CRISTATUS.
}

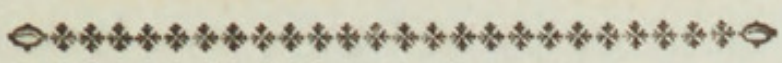

\section{CHARACTER GENERICUS.}

Roftrum tenue, depreffum, latum, bafi fetis patulis.

Nares ovatæ, parvæ.

Pedes grefforii, digitus exterior medio bafi connexus.

$$
\text { Lath. ind. orn. p. } 26_{5} .
$$

CHARACTER SPECIFICUS, EC.

TODUS crifta coccinea, corpore fufco albo-maculato.

$$
\begin{aligned}
& \text { Lin. Syft. Nat. Gmel. p. } 446 . \\
& \text { Naturf. 17. p. } 21 \text {. n. 5. t. } 1 \text {. }
\end{aligned}
$$

TODUS regius $\beta$.

$$
\text { Lath. ind. orn. p. }
$$

Avicula hæc in Guinea præcipue reperta, fedem fibi jure vindicat inter pulcherrimas fui generis. Magnitudinem naturalem oftendit tabula. 


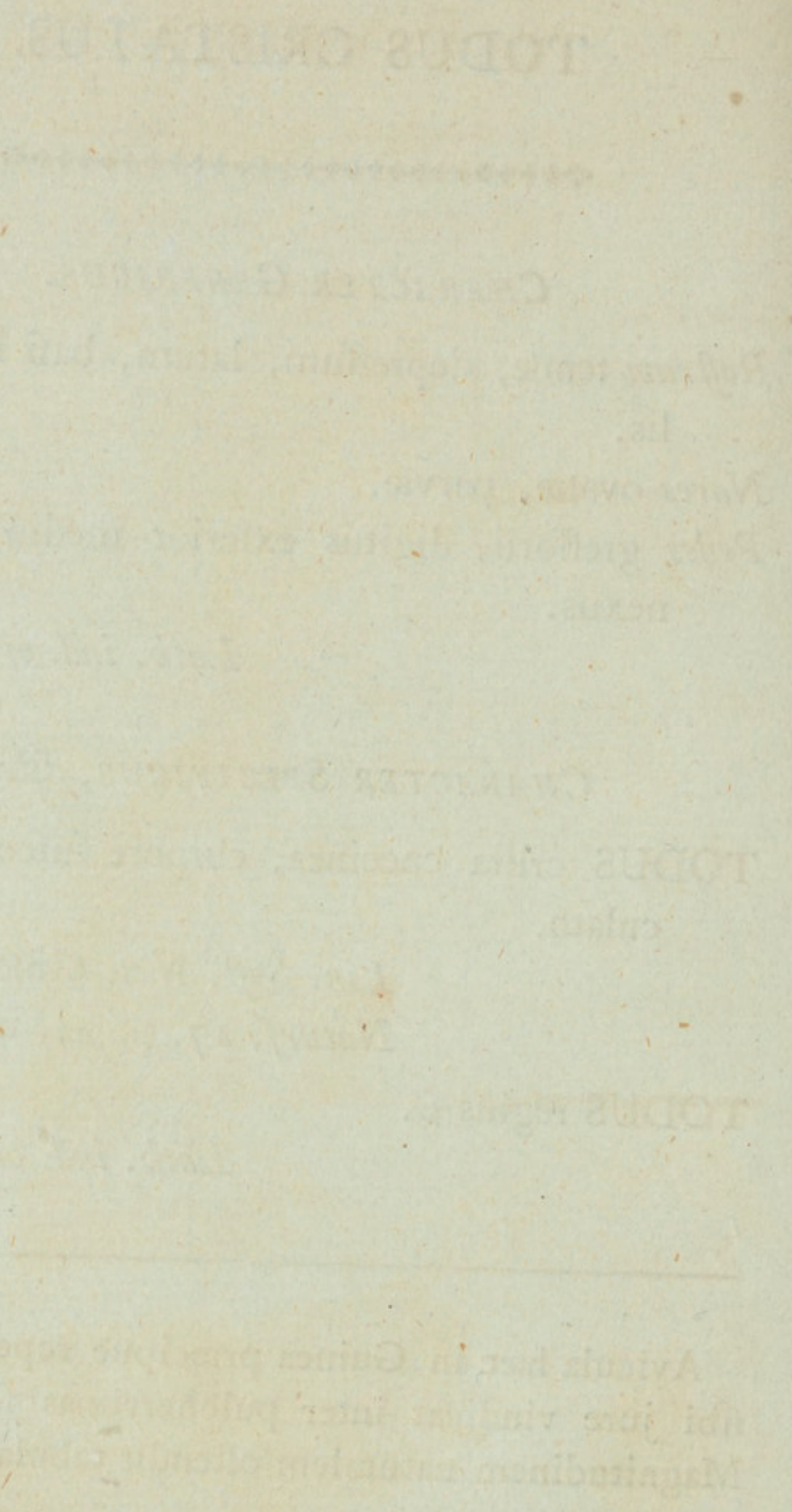




\section{,}




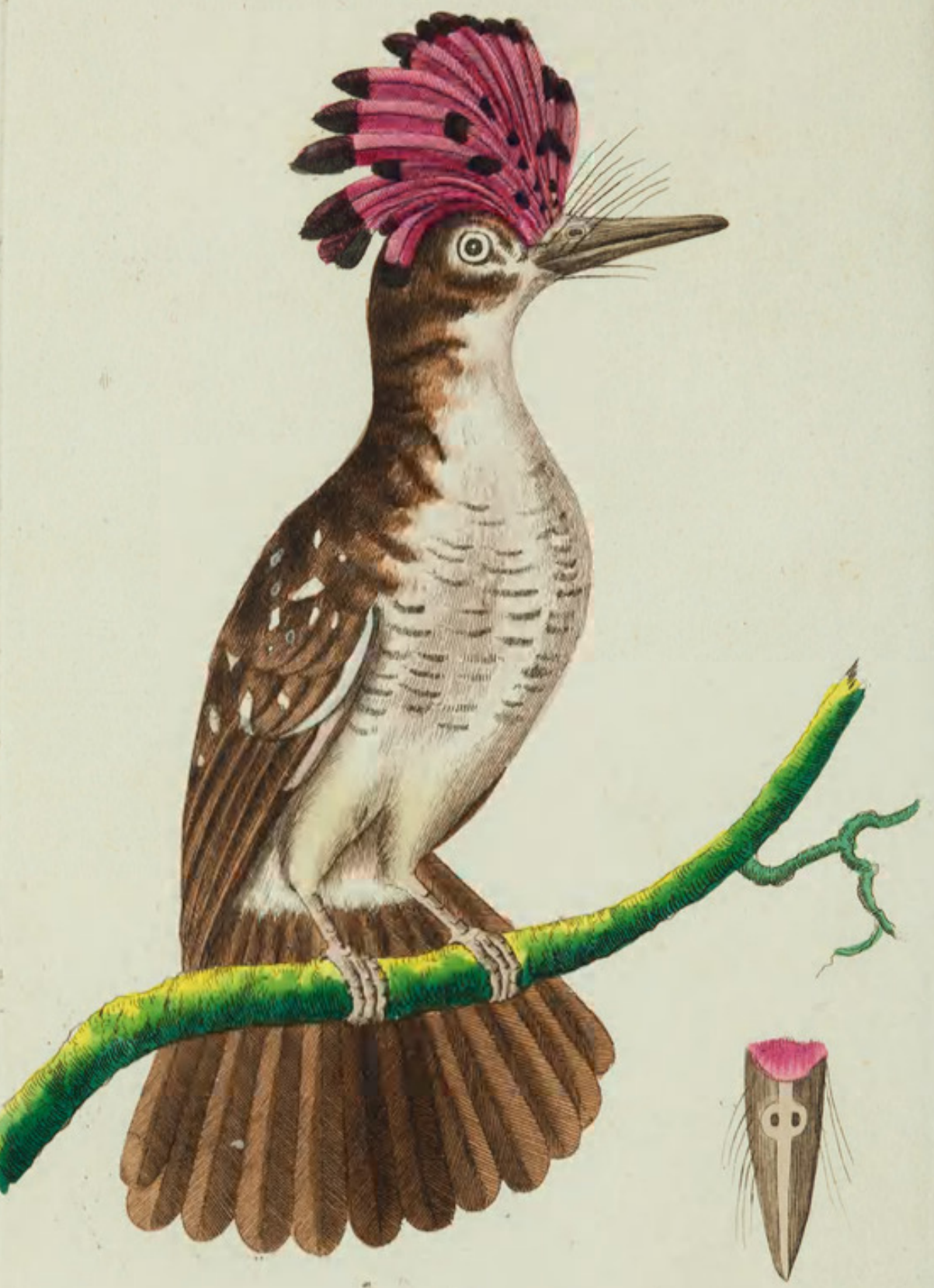


T H E

\section{CRESTED TODY.}

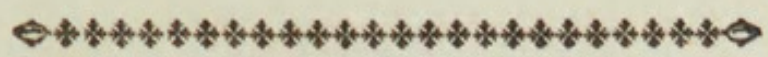

\section{GENERIC CHARACTER.}

Bill thin, depreffed, broad, with fpreading briftles at the bafe.

Noftrils fmall, ovate.

Feet grefforial : the exterior toe connected with the middle at the bafe.

\section{SPECIFIC CHARACTER.}

Brown TODY, fpotted with white, with crimfon creft, tipped with black.

This fpecies, which may juftly be confidered as one of the moft beautiful of its genus, is chiefly found in Guinea. It is reprefented on the plate in its natural fize. 


\section{$2 \mathrm{BHL}$ Biodiversity Heritage Library}

Shaw, George. 1799. "The Crested Tody, Todus cristatus [PI. 405]." The Naturalist's Miscellany 11(CXXIII), https://doi.org/10.5962/p.310852.

View This Item Online: https://www.biodiversitylibrary.org/item/276496

DOI: https://doi.org/10.5962/p.310852

Permalink: https://www.biodiversitylibrary.org/partpdf/310852

\section{Holding Institution}

Museums Victoria

\section{Sponsored by}

Atlas of Living Australia

\section{Copyright \& Reuse}

Copyright Status: Public domain. The BHL considers that this work is no longer under copyright protection.

This document was created from content at the Biodiversity Heritage Library, the world's largest open access digital library for biodiversity literature and archives. Visit BHL at https://www.biodiversitylibrary.org. 